\title{
Diving beetles (Coleoptera: Adephaga: Dytiscidae) of Namdapha National Park, Arunachal Pradesh, India
}

\author{
Sujit Kumar Ghosh* \\ Zoological Survey of India, 'M'Block, New Alipore, Kolkata - 700053, West Bengal, India; sujitghosh45@yahoo.com
}

\begin{abstract}
The present study deals with a small collection of diving beetles under the family Dytiscidae from different water bodies of Namdapha National Park, Arunachal Pradesh during 1982 to 1987. Till date, there is no published information available on this group from this national park even; the fauna of the state of Arunachal Pradesh has not been studied adequately. A total of 178 examples were studied for the first time which resulted in the identification of 10 species under 6 genera belonging to the 5 subfamilies of Dytiscidae. Out of ten species, 8 have been recorded for the first time from the state. The distribution of each species, recorded from the national park, in India is briefly summarized here.
\end{abstract}

Keywords: Diversity, Distribution, Species List, Taxonomy

\section{Introduction}

The current knowledge of the diving beetle fauna of the state of Arunachal Pradesh and North-east India have been very poorly investigated till date. Both the areas are the recognized biodiversity hotspots of the world and are highly diverse regarding the floral and faunal composition. As far as the diversity of aquatic beetles in the state of Arunachal Pradesh is concerned, few scattered publications are so far being made on the group. Only 16 species of family Dytiscidae are known from the state (Ghosh and Nilsson, 2012; Ghosh and Sinha, 2016).

The present study is based on a small collection of Namdapha National Park, collected during the expedition in between the years 1982-1987, under the leadership of Late Dr. S. Biswas, former Scientist of Zoological Survey of India, Kolkata. Dr. Biswas collected materials of various beetle families from different habitats and regions of the National Park. Author examined and studied the examples of all dytiscid collection of the expedition, which resulted in the identification of 10 species under 6 genera belonging to the 4 subfamilies of Dytiscidae. The distribution of each species, recorded from the national park, in India is briefly summarized here. The material was identified or the help of following literature: Vazirani (1969; 1970) and Brancucci (1982; 1983; 1988; 2006).
Author dealt 10 species under 6 genera of diving beetles from this national park. Eight species $\left(^{*}\right)$ are new record from Arunachal Pradesh and all 10 species are first time recorded from Namdapha National Park. Altogether 26 species are known from the Arunachal Pradesh state.

\section{Material and Methods}

All the specimens collected by Dr. S. Biswas and party during 1982 to 1987 and author got the specimen popper pining and labelling condition.

\section{Study Area}

According to the area, Namdapha National Park of Arunachal Pradesh state is the third largest National Park in India, and also it is the largest protected area in the Eastern Himalaya, which is recognized as one of the biodiversity hotspots of the world. The Namdapha National Park is situated in Changlang district in Arunachal Pradesh of Northeast India and its international border with Myanmar. The area of National Park is 1808 sq. $\mathrm{km}$ in the core zone and 1985 sq. $\mathrm{km}$ in buffer zone. The park has mainly covered with bamboo forests and secondary forests in addition to the primary forests.

\section{* Author for correspondence}




\section{List of Species}

Family DYTISCIDAE

Subfamily AGABINAE

Genus Platambus Thomson, 1859

1. Platabmus balfourbrownei Vazirani, $1965^{\star}$

2. Platambus fletcheri Zimmermann, $1928^{*}$

Subfamily COLYMBETINAE

Genus Rhantus Dejean, 1833

3. Rhantus sikkimensis Regimbart, 1899*

4. Rhantus suturalis (W.S. Macleay, 1825)*

Subfamily DYTISCINAE

Genus Sandracottus Sharp, 1882

5. Sandracottus manipurensis Vazirani, 1969*

Genus Cybister Curtis, 1827

6. Cybister tripunctatus lateralis (Fabricius, 1798)

7. Cybister sugillatus Erichson, 1834

Genus Hydaticus Leach, 1817

8. Hydaticus ricinus Wewalka, 1979*

9. Hydaticus satoi satoi Wewalka, 1975*

Subfamily LACCOPHILINAE

Genus Laccophilus Leach, 1815

10. Laccophilus chinensis Boheman, $1858^{\star}$

\section{Systematic Account}

\section{Platabmus balfourbrownei Vazirani, $1965^{\star}$}

(Figure 1)

Material examined: District Changlang, Namdapha, Miao, 14.xii.1983, coll. S. Biswas, lex. (24152/H4A); Gandhigram, 27.i.1987, coll. S. Biswas, 1ex. (24153/H4A).

Distribution: India: Arunachal Pradesh, Meghalaya, Uttarakhand and West Bengal (Ghosh and Nilsson, 2012). Elsewhere: China, Nepal and Thailand (Ghosh and Nilsson, 2012).

\section{Platambus fletcheri Zimmermann, $1928^{\star}$}

(Figure 2)

Material examined: District Changlang, Namdapha, Gandhigram, 20.i.1985, coll. S. Biswas, 1 ex. (24154/ H4A).

Distribution: India: Arunachal Pradesh and Meghalaya (Ghosh and Nilsson, 2012).
3. Rhantus sikkimensis Regimbart, $1899^{\star}$

Material examined: District Changlang, Namdapha, Miao, 02.xii.1982, coll. S. Biswas, 1ex. (24155/H4A); Deban, 06.xii.1982, coll. S. Biswas, 2 ex. (24156/H4A).

Distribution: India: Arunachal Pradesh, Himachal Pradesh, Meghalaya, Punjab, Sikkim, Uttarakhand, Uttar Pradesh and West Bengal (Ghosh and Nilsson, 2012). Elsewhere: Bhutan, China, Myanmar, Nepal and Pakistan (Ghosh and Nilsson, 2012).

\section{Rhantus suturalis (W.S. Macleay, 1825)*}

Material examined: District Changlang, Namdapha, Gandhigram, 20.i.1985, coll. S. Biswas, 1ex. (24157/H4A); 27.i.1987, coll. S. Biswas, 47ex. (24158/H4A)/H4A).

Distribution:India: ArunachalPradesh, HimachalPradesh, Jammu \& Kashmir, Meghalaya and Sikkim (Ghosh and Nilsson, 2012). Elsewhere: Afghanistan, China, Cyprus, Indonesia, Iran, Iraq, Israel, Japan, Kazakhstan, Kuwait, Kyrgyzstan, Mongolia, Myanmar, Nepal, New Caledonia, North Korea, Pakistan, Russia, Saudi Arabia, South Korea, Tajikistan, Turkey, Turkmenistan, Uzbekistan, Australian region, Europe and North Africa (Ghosh and Nilsson, 2012).

\section{Sandracottus manipurensis Vazirani, $1969^{\star}$}

(Figure 3, 4, 5 \& 6)

Material examined: District Changlang, Namdapha, Deban, 09.xii.1982, coll. S. Biswas, 1ex. (24159/H4A); 06.xii.1983, coll. S. Biswas, 1ex. (24160/H4A); Vijaynagar, 21.xii. 1984, coll. S. Biswas, 5ex. (24161/H4A).

Distribution: India: Arunachal Pradesh, Assam and Manipur (Ghosh and Nilsson, 2012).

Taxonomic notes: While studying the aedeagus of Namdapha specimens of S. manipurensis Vazirani, 1969, it was observed that it show some variation in comparison to the illustrations of aedeagus (holotype), provided by Vazirani (1969: 275B). Therefore, the holotype of $S$. manipurensis Vazirani, 1969 was re-examined and it was found that the base of the aedeagus is detached and which was reflected in the diagrams, provided with the original description of the species by Vazirani (1969). To confirm 
the identity of the species, paratype was also examined and compared with aedeagus of Namdapha specimens, and found to be identical with Namdapha materials. Therefore, here the illustrations of aedeagus of holotype (Figure 6), paratype (Figure 5) and of new material (Figure 4) to confirm the identity of the species.

\section{Cybister tripunctatus lateralis (Fabricius, 1798)}

Material examined: District Changlang, Namdapha, Gandhigram, 26.xii.1984, coll. S. Biswas, 06ex. (24162/ H4A); 20.i.1985, coll. S. Biswas, 08ex. (24163/H4A); 27.i.1987, coll. S. Biswas, 08 ex. (24164/H4A).

Distribution: India: Arunachal Pradesh (Ghosh and Sinha, 2016), Chhattisgarh (Ghosh et al., 2014), Andaman \& Nicobar Islands, Andhra Pradesh, Assam, Delhi, Gujarat, Himachal Pradesh, Jammu \& Kashmir, Karnataka, Madhya Pradesh, Maharashtra, Manipur, Meghalaya, Odisha, Rajasthan, Sikkim, Tamil Nadu, Tripura, Uttarakhand, Uttar Pradesh and West Bengal (Ghosh and Nilsson, 2012). Elsewhere: Afghanistan, Bangladesh, Bhutan, Myanmar, Nepal, Pakistan, Sri Lanka, China, Cyprus, Iran, Iraq, Japan, Kyrgyzstan, Mongolia, Russia, Syria, Tajikistan, Turkmenistan, Turkey, Uzbekistan and Europe (Ghosh and Nilsson, 2012).

\section{Cybister sugillatus Erichson, 1834}

Material examined: District Changlang, Namdapha, Gandhigram, 27.i.1987, coll. S. Biswas, 10ex. (24165/ H4A).

Distribution: India: Arunachal Pradesh (Ghosh and Sinha, 2016), Chhattisgarh (Ghosh et al., 2014), Himachal Pradesh (Ghosh, 2011), Assam, Bihar, Madhya Pradesh, Maharashtra, Manipur, Odisha, Sikkim, Tamil Nadu, Tripura, Uttarakhand, Uttar Pradesh and West Bengal (Ghosh and Nilsson, 2012). Elsewhere: Afghanistan, Bhutan, China, Indonesia, Japan, Myanmar, Nepal, Pakistan, Philippines and Sri Lanka (Ghosh and Nilsson, 2012).

\section{Hydaticus ricinus Wewalka, 1979*}

Material examined: District Changlang, Namdapha, Vijaynagar , 21.xii.1984, coll. S. Biswas, 01ex. (24166/
H4A); Gandhigram, 20.i.1985, coll. S. Biswas, 02ex. (24167/H4A); 27.i.1987, coll. S. Biswas, 14 ex. (24168/ H4A).

Distribution: India: Arunachal Pradesh, Assam, Tamil Nadu (Ghosh and Nilsson, 2012), Chhattisgarh (Ghosh et al, 2014), Himachal Pradesh (Ghosh and Hegde, 2013), Madhya Pradesh (Jaiswal et al., 2014), Maharashtra (Ghosh, 2015). Elsewhere: Afghanistan, Bhutan, Myanmar, Nepal, Pakistan, Sri Lanka, China, Laos, Thailand and Vietnam (Ghosh and Nilsson, 2012).

\section{Hydaticus satoi satoi Wewalka, $1975^{\star}$}

Material examined: District Changlang, Namdapha, Gandhigram, 27.i.1987, coll. S. Biswas, 02ex. (24169/H4A).

Distribution: India: Arunachal Pradesh, Kerala, Sikkim, Tamil Nadu and West Bengal (Ghosh and Nilsson, 2012). Elsewhere: Bhutan, Myanmar, Nepal, Sri Lanka, China, Indonesia, Japan, Philippines, Saudi Arabia, Taiwan and Thailand (Ghosh and Nilsson, 2012).

\section{Laccophilus chinensis Boheman, $1858^{\star}$}

Material examined: District Changlang, Namdapha, Deban, 05.xii.1983, coll. S. Biswas, 26 ex. (24171/H4A); 06.xii.1983, coll. S. Biswas, 39 ex. (24172/H4A); Miao, 06.xii.1983, coll. S. Biswas, 1ex. (24173/H4A).

Distribution: India: Arunachal Pradesh, Andaman \& Nicobar Islands, Assam, Himachal Pradesh, Meghalaya, Sikkim, Uttar Pradesh and West Bengal (Ghosh and Nilsson, 2012). Elsewhere: Bangladesh, Bhutan, Myanmar, Nepal, Pakistan, China, Hong Kong, Japan, Laos, Taiwan, Thailand and Vietnam (Ghosh and Nilsson, 2012).

\section{Acknowledgements}

The author is grateful to Dr. Kailash Chandra, Director, Zoological Survey of India, Kolkata for providing necessary facilities and encouragement. I am thankful to Dr. K.C. Gopi, Additional Director and Divisionalin-Charge, Entomology-A for his valuable advice. The author thanks, Dr. O. P. Srivastava, Officer-in-Charge of Coleoptera section for his support. Also thanks to Dr. Devanshu Gupta, Scientist-C, for his help. 


\section{References}

Brancucci, M. 1982. Les Platambus du sous-genre Anagabus (Col. Dytiscidae). Mitteilungen der Schweizerischen entomologschen Gesellschaft Bulletin de la Societe entomologique Suisse, 55: 115-124.

Brancucci, M. 1982. Ein neuer Platambus aus Nepal, nebst Bemerkungen zu weiteren Dort vorkommenden Arten (Coleoptera, Dytiscidae). Ento. Basil., 7: 226-230.

Brancucci, M.1983. Revision desespeces est-palearctiques, Orientales et australinnes du Genre Laccophilus (Col. Dytiscidae). Ent. Arb. Mus. Frey, 31/32: 241-426.

Brancucci, M. 1988. A revision of the genus Platambus Thomson (Coleoptera, Dytiscidae). Ento. Basil., 12: 165-239.

Brancucci, M. 2006.A review of the genus Platambus (s. str.) in the Himalayas, with the description of a new species (Coleoptera, Dytiscidae). Tijds. Ento., 149 (2005): 89-93.

Ghosh, S.K. and Nilsson A.N. 2012. Catalogue of the diving beetles of India and adjacent countries (Coleoptera: Dytiscidae). Skorvnopparn Umel Supplement, 3: 1-77.

Ghosh, S.K and Sinha B. 2016: First record of two species of Cybister Curtis, 1827 from Arunachal Pradesh (Coleoptera: Dytiscidae). Rec. zool. Surv. India, 116(Part-1): 97-98.

Nilsson, A.N. 2011: Catalogue of Palearctic Dytiscidae (Coleoptera). Internet version 2011-01-01, p. 1-50.

Nilsson, A.N. 2013: A world catalogue of the family Dytiscidae, or the diving Beetles (Coleoptera, Adephaga). Version 1.I.2013. Umea: Distributed electronically as a PDF file by the author, 304.

Vazirani, T.G. 1969: Contribution to the study of aquatic beetles (Coleoptera) 2. A review of the subfamilies Noterinae, Laccophilinae, Dytiscinae and Hydroporinae (in part) from India, Oriental Insects, 2(3-4): 211-341.

Vazirani, T.G. 1970a: Contributions to the study of aquatic beetles (Coleoptera). VII. A revision of Indian Colymbetinae (Dytiscidae). Oriental Insects, 4: 303-362.

Vazirani, T.G. 1970b. Contribution to the study of aquatic beetles (Coleoptera) V. A review of Indian Hydroporinae (Dytiscidae) in part, from India. Oriental Insects, 4(1): 93-129. 

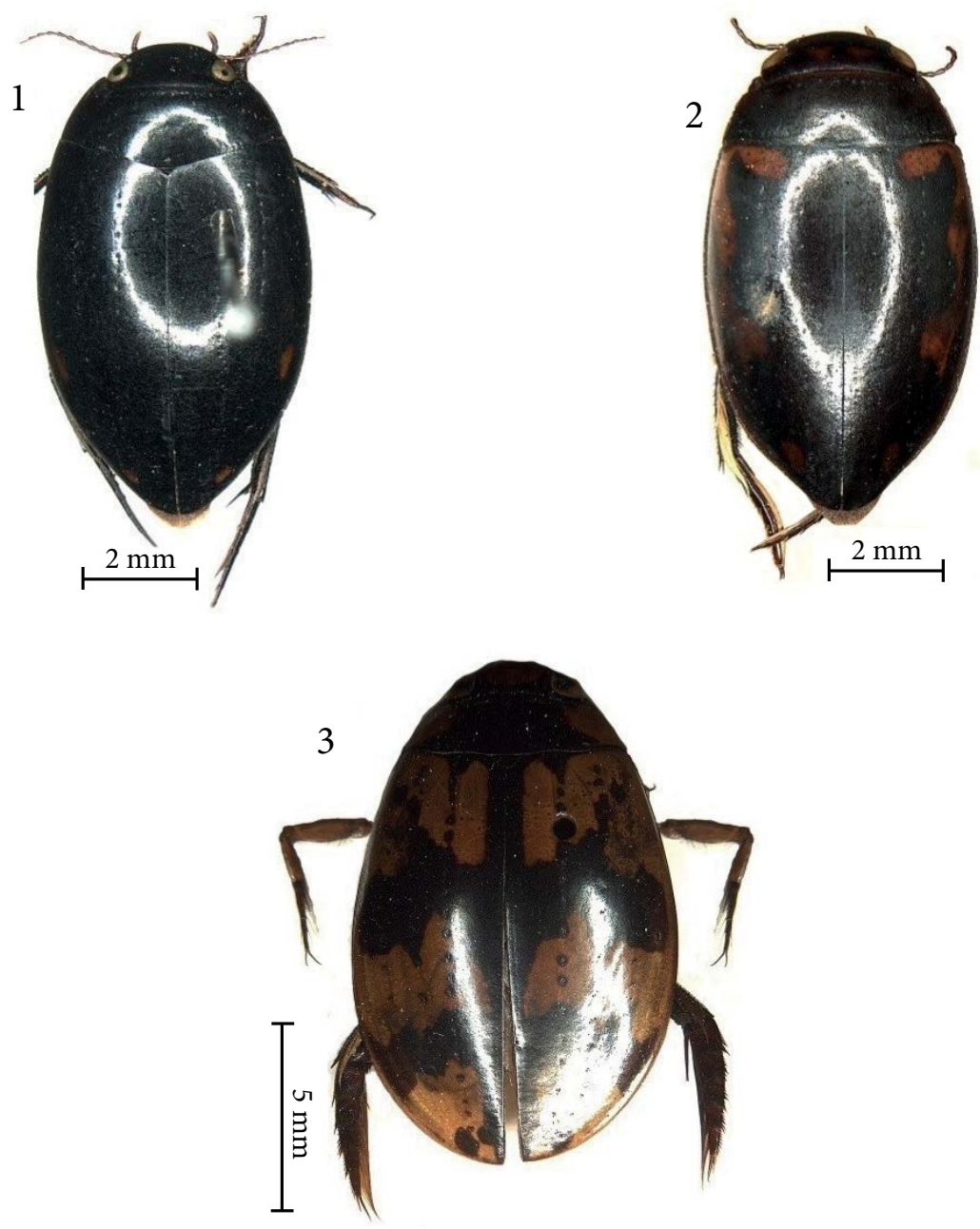

Figures 1-3. 1) Platambus balfourbrownei, 2) Platambus fletcheri, 3) Sandracottus manipurensis.
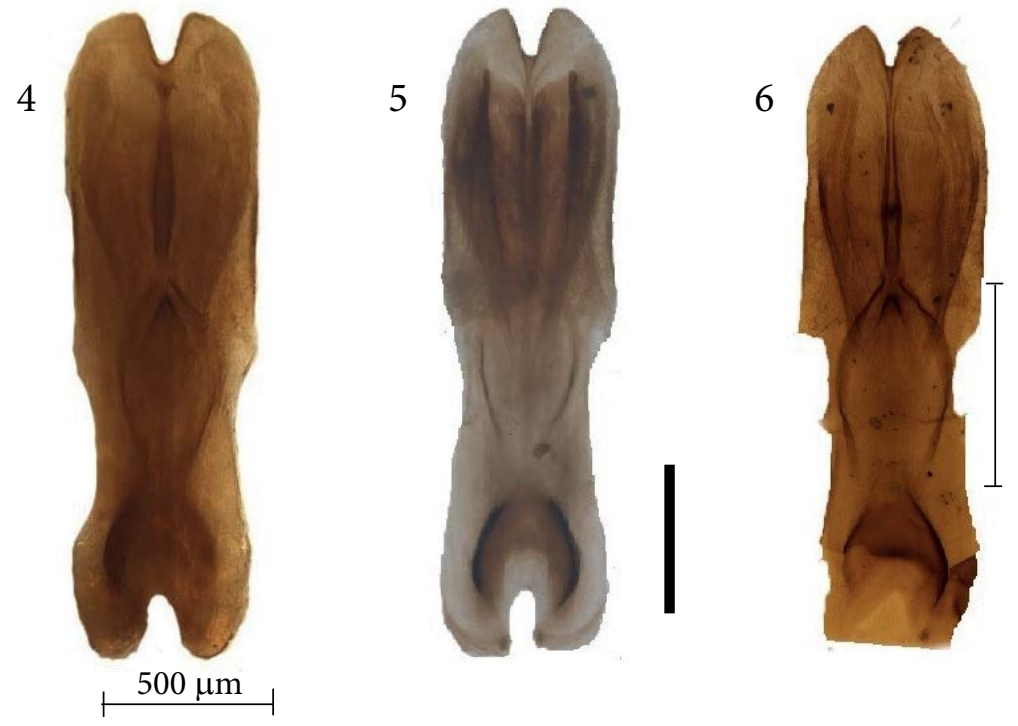

Figures 4-6. Median lobe of Sandracottus maipurensis, 4) Namdapha, 5) Paratype, 6) Holotype. 


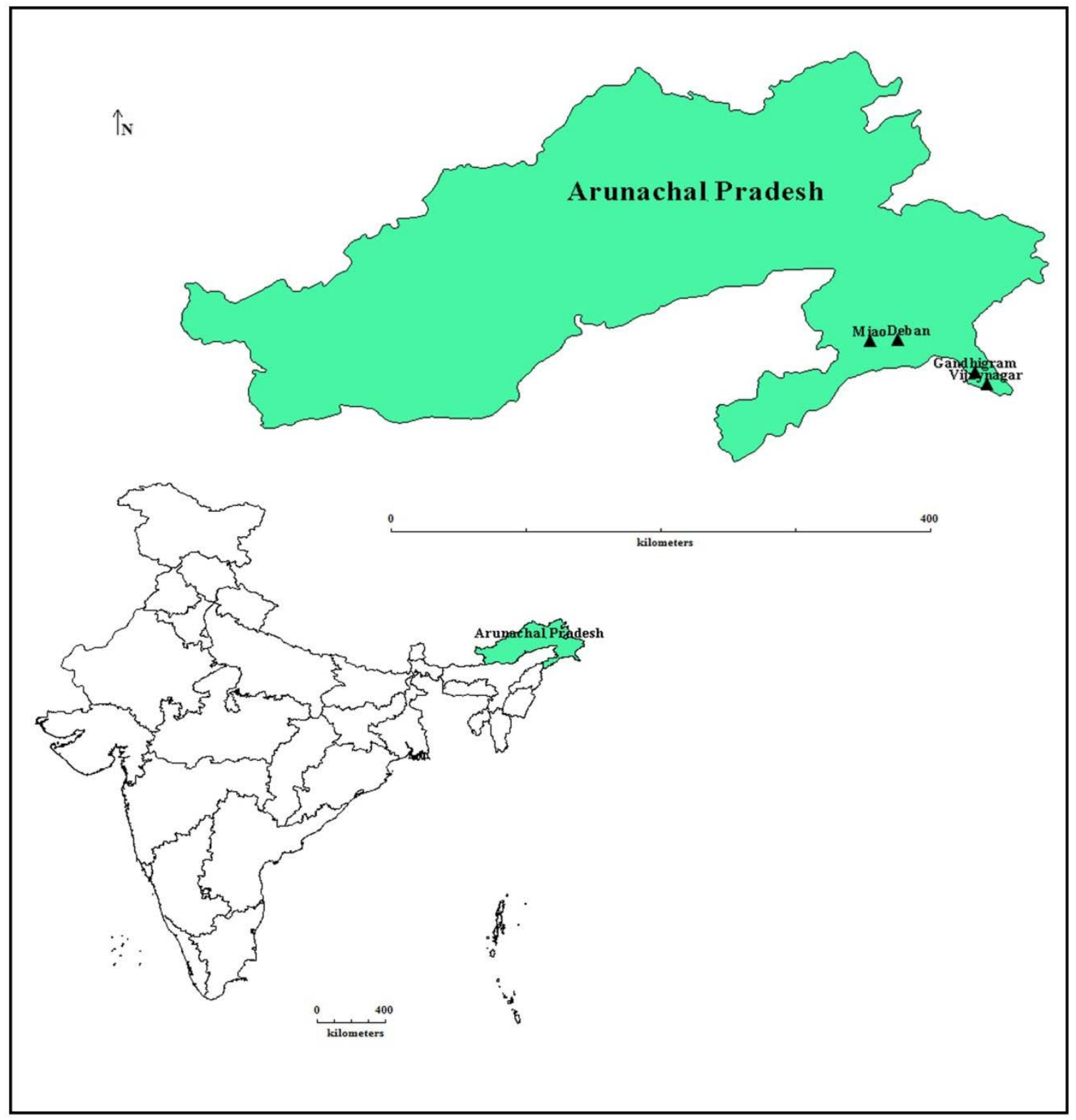

Figure 7. Map of Arunachal Pradesh of India showing the collection localities Miao, Diban, Gandhigram and Vijaynagar. 